\title{
CHEMISTRY
}

DOI https://doi.org/10.30525/978-9934-26-047-6-40

\section{ВИЗНАЧЕННЯ ВМІСТУ ВІЛЬНИХ МОНО- ТА ДИСАХАРИДІВ В СИРОВИНІ ДУБА ЧЕРВОНОГО (QUERCUS RUBRA L.)}

\author{
Коновалова О. Ю. \\ доктор фармачевтичних наук, професор, \\ завідувач кафедри фармачевтичної та біологічної хімії, фармакогнозії \\ ПВНЗ «Київський медичний університет» \\ Омельковець Т. С. \\ асистент кафедри фармачевтичної та біологічної хімії, фармакогнозї \\ ПВНЗ «Київський медичний університет» \\ Гуртовенко I. O. \\ кандидат фармачевтичних наук, \\ старший викладач кафедри фармачевтичної та біологічної хімії, \\ фармакогнозї \\ ПВНЗ «Київський медичний університет» \\ м. Київ, Украӥна
}

3 розвитком сучасної медицини зростає інтерес до препаратів рослинного походження. Це зумовлено біологічною безпечністю, значною широтою терапевтичного спектру, поступовістю нарощування клініко-фармакологічного ефекту, можливістю тривалого застосування без ризику розвитку звикання та мінімальним ризиком виникнення побічних ефектів більшості рослинних засобів. На сьогодні існує певний дефіцит ліків природнього походження, тому пошук нових видів рослинної сировини та детальне вивчення їх лікувальних властивостей $є$ актуальним.

Дуб червоний (Quercus rubra L., Fagaceae) - інвазивна рослина, що застосовується в народній медицині при простудних та вірусних захворюваннях, для підвищення імунітету та як в'яжучий засіб[4, с. 9-14], хімічний склад якого вивчений недостатньо [2, с. 1612-1621; 3, с. 5741-5745]. 
Метою даної роботи було встановити якісний склад та кількісний вміст вільних моно- та дисахаридів у сировині дуба червоного. Об'єктом дослідження були листя та однорічні пагони дуба червоного (Quercus rubra L.), зібрані у серпні 2020p. у с. Лісники КиєвоСвятошинського району, Київської області.

Дослідження проводили методом газо-рідинної хромато-масспектрометрії. Метод заснований на екстракції вільних моносахаридів та повному кислотному гідролізі сировини для визначення моносахаридного складу та отриманні ацетатів їх альдонітрильних похідних 3 подальшим хроматографічним розділенням на газовій хромато-масспектрометричній системі Agilent 6890N/5973 inert (Agilent technologies, USA). Якісний аналіз сполук проводили за часом утримання стандартів моно- та дисахаридів, кількісний аналіз - із застосуванням розчину сорбітолу в якості внутрішнього стандарту [1, с. 633-638; 5, c. 29-33].

В результаті проведених досліджень у листі та однорічних пагонах дуба червоного було ідентифіковано 5 сполук (маноза, глюкоза, галактоза, фруктоза та сахароза). Та встановлено, що за кількісним вмістом серед вільних моносахаридів переважають глюкоза (954 мг/100 г), маноза (360 мг/100 г) та дисахарид сахароза (464 мг/100 г), в незначній кількості містяться моносахариди фруктоза (43 мг/100 г) та галактоза (43 мг/100 г).

На нашу думку, досить високий вміст глюкози в листі та однорічних пагонах Quercus rubra у серпні місяці може бути пов'язаний 3 гідролітичними процесами танінів у зв'язку з дозріванням плодів та початком підготовки до осінньо-зимового періоду.

Отже, методом газо-рідинної хромато-мас-спектрометрії досліджено якісний склад та кількісний вміст вільних моно- та дисахаридів у сировині дуба червоного. Одержані результати свідчать про перспективність подальшого комплексного фітохімічного дослідження різних видів сировини дуба червоного.

\section{Література:}

1. Guerrant G.O., Moss C.W. Determination of monosaccharides as aldononitrile, O-methyloxime, alditol, and cyclitol acetate derivatives by gas-chromatography. Analytical Chemistry. 1984. 56. P. 633-638.

2. Leaf Carbon Export and Nonstructural Carbohydrates in Relation to Diurnal Water Dynamics in Mature Oak Trees / Gersony J.T., Hochberg U., Rockwell F.E., Park M., Gauthier P.PG, et al. Plant Physiol. 2020. V. 183(4). P. 1612-1621. 
3. Quercitol: From a Taxonomic Marker of the Genus Quercus to a Versatile Chiral Building Block of Antidiabetic Agents / Worawalai W., Sompornpisut P., Wacharasindhu S., Phuwapraisirisan P. J Agric Food Chem. 2018. № 66 (23). P. 5741-5745.

4. Дебринюк М. Ю., Придка П. П. Дуб червоний (Quercus rubra L.) у лісових насадженнях Страдчівського НВЛК: поширення та лісівничотаксаційна характеристика. Науковий вісник НЛТУ України. 2013. Вип. 23 (17). С. 9-14.

5. Оленников Д. Н., Танхаева Л. М. Методика количественного определения группового состава углеводного комплекса растительных объектов. Химия растительного происхождения. 2006. №4. С. 29-33.

DOI https://doi.org/10.30525/978-9934-26-047-6-41

\title{
ВИЗНАЧЕННЯ ВМІСТУ ВІЛЬНИХ МОНО- ТА ДИСАХАРИДІВ У СИРОВИНІ ДІВОЧОГО ВИНОГРАДУ П'ЯТИЛИСТОЧКОВОГО
}

\author{
Коновалова О. Ю. \\ доктор фармачевтичних наук, професор, \\ завідувач кафедри фармачевтичної та біологічної хімії, фармакогнозії \\ ПВНЗ «Київський медичний університет»

\section{Ящук Б. О.} \\ асистент кафедри фармащевтичної та біологічної хімії, фармакогнозії \\ ПВНЗ «Київський медичний університет» \\ Гуртовенко I. O. \\ кандидат фармачевтичних наук, \\ старший викладач кафедри фармацевтичної та біологічної хімї, \\ фармакогнозії \\ ПВНЗ «Київський медичний університет» \\ м. Київ, Украӥна
}

Дівочий виноград п'ятилисточковий (Parthenocissus quinquefolia) північноамериканська деревоподібна листопадна ліана родини Vitaceae, по всьому світу культивується як декоративна рослина для вертикального озеленення. Представники роду Parthenocissus використовуються в народній медицині як засоби з протизапальною, загально154 